\title{
Seeing "RED" to Serve Students: An Example of Advocacy for Counseling Services for Refugee and Immigrant Adolescents
}

\author{
Lisa Hoffman \\ Indiana University Southeast \\ Shifa Podikunju-Hussain \\ Indiana University Southeast \\ Melissa Fry \\ Indiana University Southeast
}

\begin{abstract}
The purpose of this study was to examine to what extent a U.S. newcomer school for adolescent English language learners lacked adequate mental health services for immigrant students. School counseling professionals at this school sought data to advocate for additional mental health professionals without asking inappropriately invasive questions about family legal immigration status. Leveraging the expertise of school administrators, refugee resettlement experts, and university researchers yielded a creative method for collecting student demographic information without violating student privacy. Looking specifically at refugee students from highconflict backgrounds (the "refugees likely to have experienced distress" or "RED" variable) allowed researchers to pinpoint psychosocial acculturation differences in comparison with other immigrant students. A survey of students revealed differences in reported attitudes toward school and perceptions of discrimination among refugees from high-conflict backgrounds compared to other immigrants and refugees from lower-conflict backgrounds. Findings also supported the notion that immigrant students were likely to have experienced trauma prior to enrolling in this school. Results of this engaged scholarship allowed the resident school counselor to advocate effectively for a full-time mental health counselor position for newly arrived secondary students.
\end{abstract}

Keywords: acculturation; refugees; immigrants; adolescents; education 


\section{Introduction}

Recent international news headlines have been filled with stories about immigrant and refugee children, and many of these stories involve children suffering trauma. From Syrian families taking treacherous journeys on rafts to escape civil war to migrant children being forcibly separated from their parents at the U.S.-Mexico border, current events related to international migration often involve trauma inflicted upon children. Research at refugee camps has shown that posttraumatic stress disorder symptoms among Syrian refugee children may be ten times more common than among children globally (Sirin \& Rogers-Sirin, 2015). Refugee camps themselves, which are intended to provide temporary safe havens for families fleeing life-threatening circumstances, can be overcrowded and violent and present additional sources of childhood trauma (Ghumman, McCord, \& Chang, 2016). Children whose immigrant parents have been deported or detained have higher reported incidence of psychological stress than other children with immigrant parents (Rojas-Flores, Clements, Hwang Koo, \& London, 2017). Even immigration policies and practices themselves-such as the forced family separations at the U.S.-Mexico border - can exacerbate the trauma of treacherous and exploitative migration journeys (Roth, Crea, Jani, Underwood, Hasson, Evans, \& Zuch, In press; Torres, Santiago, Walts, \& Richards, 2018).

Despite the prevalence of traumatic stress among immigrant and refugee children, many schools in the United States do not have the necessary resources and personnel to provide counseling and mental health services to these children. School officials often do not know the background of newly enrolled students, and schools are legally prohibited from asking about students' or families' immigration status (U.S. Department of Justice and U.S. Department of Education, 2014). How can schools collect data about students likely to need counseling resources and thus justify more resources for mental health services? This case study gives one example of a school using a creative method of collecting information about increased need for counseling services among immigrant students while still protecting their privacy. The study began with the following questions:

1. Do students who came to the United States as refugees from distressed areas report different areas/levels of acculturative stress compared to students who came to the U.S. through other immigration channels?

2. How can schools use other data points to predict whether their student population is more likely to need mental health or school counseling services?

The aim of this exploratory study was to create a method that would allow school counselors to anticipate how many newcomer immigrant students were likely to need counseling or mental health services, all while respecting the confidentiality of immigrant families' legal status or personal histories of trauma. Our hypothesis was that students who entered the U.S. as refugees from countries where they were more likely to have experienced traumatic stress (such as conditions of war) would be more likely to demonstrate a need for mental health services.

The impetus for this study came amid sharp enrollment increases in a public school serving adolescent English language learners. The school counselor was frustrated by inadequate resources to address the needs of increasing numbers of students with symptoms of trauma. For example, two students arrived in the United States and immediately enrolled at the newcomer school during the same week researchers collected data for this study. One of these students had lost a limb to an explosion in Iraq and was suffering from constant pain due to shrapnel still in her body. She also displayed symptoms that school staff assumed to be undiagnosed and untreated post-traumatic stress disorder. The other new student was 16 years old but had not attended school for the previous ten years due to multiple displacements and years spent in refugee camps in Thailand. The

(c) 2018 Hoffman, et al. Free to copy and share for education and scholarship under a Creative Commons Attribution NonCommercial-

NoDerivatives 4.0 License. 
acculturation stress and psychological needs of these two students could differ significantly from the needs of students who did not experience such trauma prior to their arrival in the United States. The school counselor saw a need for more mental health resources for the school but needed data documenting the need in order to request resources from her school district. She turned to a local university researcher for help. Although the project had no budget and a limited timeframe, a small team of researchers agreed to try to find ways to answer the research questions. The school counselor took the findings to the school district, which funded her request for a dedicated full-time mental health counselor on campus to serve immigrant and refugee secondary students. We share this success to encourage other school systems and social service organizations to seek creative avenues for increasing counseling opportunities for immigrant and refugee children.

\section{Literature Review}

The effects of trauma on students' long-term mental health and ability to learn has been well-documented (Hurt, Malmud, Brodsky, \& Gianetta, 2001; Rossen \& Cowan, 2013). Scholarship on adverse childhood experiences (ACEs) and the lifelong consequences of untreated traumatic stress has highlighted the need for "trauma-sensitive" and "trauma-informed" school and community services (Cole, O'Brien, Gadd, Ristuccia, Wallace, \& Gregory, 2005; Oehlberg, 2008; Craig, 2016; Felitti, Anda, Nordenberg, Williamson, Spitz, Edwards, Koss, \& Marks, 1998). Among immigrant students, traumatic experiences in the home country can affect adjustment to life in the new country (Ghumman, McCord, \& Chang, 2016; Porter \& Haslam, 2005). When students enter a school district from another country, school officials often do not know the circumstances behind their immigration. School psychologists and school counselors need to understand the acculturation issues and stresses that immigrant and refugee students are likely to face (Cisneros \& Lopez, 2016). Previous research has shown that refugee adolescents prefer accessing mental health services at school rather than home or clinical settings (Fazel, Garcia, \& Stein, 2016). Researching immigrant students' needs is a critical way for psychology and counseling professionals to advocate for social change among marginalized populations (Yakushko \& Morgan Consoli, 2014).

\section{Distinctions between Refugees and Immigrants}

Both political and sociological definitions of immigrants and refugees can differ. The United Nations considers a refugee to be someone forced to flee a home country because of persecution, war, or violence (UNHCR, 2018a). Common sociological definitions include Segal and Mayadas's (2005) distinction between immigrants pulled to a host country by its attraction as compared to life in the home country, and refugees pushed from their home country due to extenuating circumstances such as war or life-threatening persecution. However, this description does not reflect the experiences of many recent migrants to the U.S. from Central America. Popular media documents many migrant families fleeing gang-related violence-being "pushed" from their homes, in other words-yet these families do not enter the U.S. with refugee status. From a legal standpoint, the United States labels as "refugee" only those immigrants who have applied for refugee status before they enter the U.S. and who have been granted legal refugee status by the U.S. Department of Homeland Security while they are still overseas (U.S. Citizenship and Immigration Services, 2015). An individual who arrives to the United States and then asks permission to stay due to threat of violence or fear of persecution is applying for legal asylum ((U.S. Citizenship and Immigration Services, 2015). Both asylees and refugees have legal status in the U.S. However, refugees received their legal acceptance before making the trip to the United States. Asylum can only be granted once an individual has already reached U.S. soil.

While the titles "refugee" and "immigrant" may indicate distinctions in immigration pathways, the two groups are not clearly differentiated in other ways. Both refugees and immigrants may come from widely divergent economic circumstances, cultural backgrounds, and political systems which may affect the immigration experience. For clarity, this paper refers to "refugees" as those who have legal refugee status conferred by the U.S. government. We use the term "immigrant" to refer to those who have come to the U.S. 
by any other channel besides formal refugee resettlement. We do not know if any students in this study have legal asylee status because, as we will explain below, schools are not allowed to ask students or families about their immigration status. However, the number of legal asylees in this community in general was very small at the time of this study, particularly compared to the number of refugees in this community; using categories of "refugee" and "immigrant" is more salient to the community demographic at the time of data collection.

A key point underpinning this study is that the legal distinction between refugees and immigrants does not necessarily correspond to a distinction in experiences of trauma. Historically, many refugees come from high-conflict situations such as countries experiencing war. Indeed, Doran-Myers and Davies (2009) found that refugees from countries in conflict are more likely to have experienced trauma prior to arriving in the U.S. as compared to other immigrants. Yet not all refugees fit into this category. For example, at the time of data collection the largest single group at the school in this study were Cuban-born refugees. Although these students had legal refugee status, most did not come from violent or high-conflict situations. Conversely, non-refugee immigrants may have been exposed to significant violence and significant trauma in their home countries. For example, after the data collection for this study, the newcomer school saw an increase in students arriving from Guatemala, El Salvador, and Honduras - countries with high rates of gang-related violence. Most students from these countries do not have refugee status, but they may still have experienced traumatic stress similar to children coming from countries at war. Much media attention has focused recently on Central American "border crossers" who seek asylum upon first setting foot in the United States and risk deportation if asylum is denied. For the purposes of considering student trauma, though, it's worth noting that many asylum seekers enter the country on tourist visas or work visas or student visas and then hire private attorneys to handle their asylum applications. The largest number of asylum applicants in the U.S. is actually from China (Transactional Records Access Clearinghouse, 2016). Whether legal asylum is granted or denied may not correspond to the experience of traumatic stress or physical danger in one's home country. Asylees from China may be less likely to have experienced traumatic stress or migratory stress than asylees from Guatemala. Yet increased reports of violence in Central America notwithstanding, asylum denial rates by U.S. immigration courts have risen each year for the last five years. Asylum seekers from Mexico are the most likely to have asylum status denied, with an almost 90\% denial rate in immigration court (Transactional Records Access Clearinghouse, 2016).

Regardless of a student's path to the United States, schools do not keep records of immigration status or whether a student arrived as a refugee or not. The 1982 U.S. Supreme Court ruling Plyler v. Doe determined that children have a right to free public schooling regardless of their immigrant status. This directive also prohibits schools from requiring any information that would necessitate parents revealing potential undocumented status. These guidelines protect the rights of all children in the U.S. to attend school and are also intended to allay parents' fears that schools might report children who do not have legal immigrant status (U.S. Department of Justice and U.S. Department of Education, 2014). Schools' sparse background information about students drives this study's investigation of ways schools might appropriately obtain valuable information to serve students with extra psychosocial needs due to immigration-related stress.

\section{Trauma and Adjustment to a New Culture}

School psychologists and researchers alike have long noted the importance of understanding the struggles and issues facing immigrant and refugee students (Dodds, 2010; McCloskey \& Southwick, 1996; Reyes \& Elias, 2011; Zhou, Peverly, Xin, Huang, \& Wang, 2003). Whether a child enters a new country as a refugee or an immigrant, he or she may experience high levels of stress due to experiences of immigration and acculturation. Birman and Chan (2008) identified traumatic stress from acutely distressing experiences suffered prior to immigration, migration stress from the process of uprooting from previous support systems, and acculturative stress from the process of adjusting to a new host culture. 
Refugee children's exposure to traumatic events has been linked to increased difficulty adjusting to a new culture and an elevated risk of mental health problems (Birman, Ho, Pulley, Batia, Everson, Ellis, Stichik Betancourt, \& Gonzalez, 2005; Doran-Myers \& Davies, 2009; Shannon, Vinson, Wieling, Cook \& Lett, 2015; Walick \& Sullivan, 2015). Commonly reported effects of traumatic stress among refugees include depression, anxiety, sleep disturbance, survivor's guilt, aggression, internalization of problems, learning difficulties, and impacted academic performance (Center for Victims of Torture, 2005; Hurt et al, 2001; Nugent \& Roberts, 2013; Rossen \& Cowan, 2013; Sirin \& Rogers-Sirin, 2015). However, the acculturation process of refugee youth is multidimensional (Trickett \& Birman, 2004) and the direct effect of refugees' traumatic stress, migration stress, and acculturative stress on mental health is not well understood (Kartal \& Kiropoulos, 2016).

Migration stress refers to trauma caused by the process of immigration. Examples of migration stress could include Syrian refugees crossing the Mediterranean in an overcrowded raft or unaccompanied children from El Salvador sneaking on a train to Mexico and then crossing the desert to the U.S. with human smugglers. In some cases, the process of migration itself may take decades. Refugees from many countries live in stressinducing circumstances in refugee camps for years before being resettled in the U.S. (Ghumman, McCord, \& Chang, 2016).

Once in the host country, acculturative stress can also be linked to posttraumatic stress symptoms among refugees (Bentley, Thoburn, Stewart, \& Boynton, 2012; Ellis, MacDonald, Lincoln, \& Cabral, 2008). Regardless of the circumstances precipitating immigration, the process of creating a new life in a new country can be stressful for any child. By definition, immigrant and refugee children are separated from home cultures, communities, and extended family members (Knipscheer, Drogendijk, Gülsen, \& Kleber, 2009). School-based interventions are among the recommendations for overcoming acculturative stress (Kia-Keating \& Ellis, 2007; Tyrer \& Fazel, 2014).

\section{Creating a Construct for School-Based Data Collection}

The literature noted above supported the researchers' concern that the newcomer school needed to increase capacity to meet the mental health and acculturation needs of their growing student population. Increasing capacity would necessitate predicting how many newcomer children would be likely to need counseling services. However, asking students or parents about their immigration experiences would not be appropriate due to the legal restrictions discussed above. Asking refugee resettlement agency caseworkers for a client list could also pose a privacy problem for families; in addition, it may not yield the data the school needs because legal refugees did not all undergo high-conflict or traumatic experiences. Using a single data point such as students' birthplace would not be enough, either. By definition, refugees flee from their home country to another country. (People fleeing for their lives who do not cross a nation-state boundary are instead called "internally displaced persons.") Refugees resettled in the United States are usually in at least their third country. Because of this, a refugee child who is part of a persecuted ethnic group in Myanmar (Burma) may have been born in a refugee camp in Thailand, Malaysia, or Bangladesh. Sorting students by nationality, ethnic group, or language poses additional complications. Some refugees are "stateless people," such as Meskhetian Turks who are an ethnically Turkish minority group in the former Soviet Union who were deported by Stalin from Georgia to other countries of the former U.S.S.R. during World War II. Some Meskhetian Turks, including many in Russia, had no citizenship or national identity in any country until being resettled by the United Nations High Commission for Refugees in the last decade (Aydıngün, Harding, Hoover, Kuznetsov, \& Swerdlow, 2006). Students from this group of resettled refugees had no former citizenship in any country. They might record their ethnicity and/or nationality as Turkish, Russian, Georgian, Ukrainian, Uzbek, or any of a number of other identifiers.

After discussing these complications and the need for this study with both school personnel and refugee resettlement agency caseworkers, we realized that we needed a construct which could be continually adapted 
and updated to reflect quickly-changing immigration patterns. Adaptability in data collection is critical because the U.S. State Department sets different quotas each year to limit the number and countries of origin of refugees admitted to the United States. In one year the U.S. may have accepted many Meskhetian Turks, for example, but in the following year no Meskhetian Turks may arrive and the Office of Refugee Resettlement may plan to accept the largest number of refugees from the Democratic Republic of Congo. Immigration patterns change from year to year among non-refugees, too. Economic and political upheavals often affect annual arrivals of non-refugee immigrants from different parts of the world. For example, fewer immigrants arrived to the US from Mexico in 2017 than in 2016. However, more individuals from El Salvador, Guatemala, and Honduras sought asylum from 2013-2015 than in the previous 15 years combined (Mossaad, 2016). These examples illustrate that immigration trends and patterns among both refugees and non-refugee immigrants can change quickly and often.

The analytical construct we developed, "Refugees likely to have Experienced Distress" (or "RED”), allowed us to be adaptable and responsive to current events and changing immigration patterns as we analyzed student data in order to be sensitive to the needs of students who have experienced trauma. Understanding the needs of English language learners-and all newcomer students-requires attention to the social and political realities that shape their acculturation needs. When it comes to serving students, context matters-and educators and counselors alike must stay abreast of the social and cultural contexts of students' lives.

\section{Methods}

The study seeks to identify differences in the acculturation experiences of English Language Learners (ELLs) using a cross sectional survey of students in a magnet program for ELL students. The primary investigators recognized acculturation was likely to vary between students arriving from war-torn or otherwise violent or oppressive countries (often via refugee camps) and those immigrating under less stressful conditions. Grappling with inconsistencies in student knowledge of their national and ethnic backgrounds, the research team identified the need to develop a tool for identifying group differences based on exposure to traumatic stress-something we could not directly ask about and that we could not directly ascertain using only incomplete responses to questions about students' country of origin. Inconsistencies in student responsiveness combined with complex interactions between place and ethnicity meant we needed a method to determine which students were likely to have experienced distress prior to their arrival in the U.S. We expected that triangulating parents' origins and language would give us a more accurate understanding of students' experience prior to arrival than would just the students' responses to the question of their own country of origin.

Survey responses allowed us to look at relatively standard indicators of acculturative stress and migration stress. Following the creation of the analytical construct for prior experiences of distress, our objective was to examine group differences in various measures of acculturation and migration stress including perceptions of discrimination. If the construct worked as we hoped, we expected that those we identified as likely to have experienced distress would indicate symptoms of acculturative or migratory stress and experiences of discrimination with greater frequency than those who were not identified as REDs.

\section{Setting of the study}

The study was conducted at a public school serving secondary students who have recently immigrated to the United States. The school is in an urban Midwestern city in which students speak over 100 languages and around ten percent of public school students are born outside the U.S. (Oyler \& Kulkarni, 2015). Although this state has not historically been an immigrant magnet, the population of English language learners in the state increased by over 300\% in the past decade (Horsford \& Sampson, 2013). Such growth is not unique. Across the U.S., recent growth in immigrant populations has increased the most in communities that were previously 
unaccustomed to large populations of immigrants (Baird, Adelman, Reid \& Jaret 2008; Izyumov, Nahata \& Coomes, 2002).

Middle-school and high-school-aged students attending this school all have minimal English language skills and/or interrupted formal education. "Newcomer programs" such as this have become more common in the U.S. over the last two decades as the population of older immigrant children with both academic and language needs increases (Short, 2002; Short \& Boyson, 2012). In a newcomer model, newly arrived secondary students are segregated from the general population for 1-3 semesters for intensive English instruction. In addition to English, students also take grade-appropriate content area courses taught with accommodations to help support English language development. Once students reach a certain level of English proficiency, they exit the newcomer program to a mainstream school where they continue to receive English language classes and language support within a regular middle or high school building. In order to avoid a de facto segregated educational system for immigrant students, students use a newcomer school as an intensive "jump start" in English but are not permitted to stay there indefinitely.

The school in this study began in 2009 with fewer than 100 students. At the time this study was planned, enrollment was approximately 280 students representing 39 countries of origin. School enrollment continues to increase rapidly, highlighting the importance of funding staff and services for newcomer adolescent students.

The school district assigned one school counselor to the newcomer school based on the number of students enrolled. This was the only staff member on site with any training in addressing student psychosocial issues. However, the school counselor had mostly administrative duties rather than counseling duties. The school district does not provide a trained school psychologist to every school and uses school psychologists primarily for educational evaluation services.

\section{Participants}

Two hundred and sixty-one students chose to respond to some or all of the questionnaire used to collect data. Of the 261 questionnaires, 257 provided usable data on non-demographic items. Respondents ranged from age 10 to age 21 with a mean age of 14.74 and a reported average age of arrival in the U.S. of 13.33. A total of 123 girls and 114 boys responded to the sex item on the survey. Respondents reported 39 different countries of birth (see Figure 1). The largest numbers of students were born in Cuba $(n=50)$ and Nepal $(n=42)$. Both Cuban and Nepalese groups held legal refugee status at the time of this study.

At the time of this data collection, the school was providing interpretation for ten languages for instructional purposes. While students' linguistic diversity is more varied than ten languages, many students were already multilingual before entering the U.S. school system. For example, students from a number of West African countries who already spoke French as a second or third language grouped together with a French interpreter for particular events during the school day. The study used the same student groupings of ten languages with the same familiar school-sanctioned interpreters to ensure that every participant would receive instructions in a familiar setting and language.

The participant demographics in this study represent a single moment in time that cannot be replicated even within the same school in the same community. Immigration patterns shift dramatically in relatively short periods of time based on U.S. federal policy changes, global geopolitics, and economic factors. Since the data collection, for example, at least three major changes have dramatically altered the demographic composition of the school in this study. First, U.S. immigration policy has shifted regarding Cuban arrivals and they no longer automatically receive parolee/refugee status. Second, widely publicized executive orders under the Trump administration have labeled refugees from 11 majority-Muslim countries (including Somalia, Sudan, and Iraq) as "high risk" and have delayed or denied entry to thousands of refugees due to much slower security screening procedures (Robbins \& Jordan, 2018). Third, a large number of both unaccompanied minors and entire families seeking asylum have entered the U.S. from El Salvador, Guatemala, and Honduras. The United 
Nations High Commission for Refugees reports a 25 percent increase in asylum requests from 2016 to 2017 from those three countries due to increased violence (UNHCR, 2018b). These three developments represent shifts in the constantly changing demographics of this newcomer school as well as schools across the country.

\section{Instrument}

The survey used in this study included two parts: a demographic questionnaire and a modified version of the Immigrant Adolescent Questionnaire (IAQ) (Berry, Phinney, Sam \& Vedder, 2006). The fourteen demographic questions included student's and parents' ethnicity, student's place of birth, mother's place of birth, father's place of birth, student's first language, mother's first language, father's first language, and student's age of arrival in the United States. The International Comparative Study of Ethnocultural Youth administered the Immigrant Adolescent Questionnaire (IAQ) to 7,997 immigrant youth from diverse cultural backgrounds living in 13 countries of settlement around the world (Berry et al, 2006). The instrument includes subscales measuring attitudes toward school, ethnic identity, language, cultural traditions, friends, social activities, family relationships, perceived discrimination, self-esteem, psychosomatic symptoms, and negative activities. Each subscale uses a 5-point Likert scale in which responses range from "strongly disagree" to "strongly agree." The IAQ is public domain, but the researchers also contacted the lead author, John Berry, for permission to use the instrument. Examples of questions in the subsections analyzed for this project are as follows:

- School Adjustment: 9 questions such as "I have problems concentrating during classes" and "I care about my grades and how I do in my school work." Six items load on two constructs, one related to indicators of acculturative stress, such as "I have problems concentrating during class" and the other related to feelings about school, such as "I believe my teachers care about me and my success" (see Table 1).

- Perceived discrimination: 9 questions such as "Teachers have treated me unfairly or negatively because of my ethnic background" and "I don't feel accepted by Americans." When all 9 are included, Cronbach's Alpha is .809, but some items have low loadings. When we reduce to four items reliability declines slightly, but strong loadings suggest valid and reliable measurement of one underlying construct (see Table 2).

\section{Data Collection}

School administrators granted the research team one class period with students. This fifty-minute time segment had to suffice not only for the administration of the questionnaire used for data collection, but also for the survey instructions and student practice with the response sheet. This time period also included handling of the multilingual informed consent approvals distributed prior to survey administration in accordance with the university Institutional Review Board and school district research office protocols. The study would not have been possible without a team of dedicated and patient interpreters. Multilingual interpreters had become familiar with the questionnaire in advance and already knew the students well, as they were all certified interpreters employed by the school district as bilingual associate instructors. Students each had a response sheet with a five-point Likert scale for each question, and interpreters needed to take time to ensure students' understanding of the response sheet prior to survey administration.

The research team and multilingual school staff administered the survey instrument on two separate days to account for staffing needs related to linguistic diversity. On the first day of data collection, approximately 90 Spanish-speaking students-the largest language group at the newcomer school-gathered in the school auditorium for the administration of the survey in Spanish. The written survey was translated into Spanish by a local translation agency. Per Institutional Review Board requirement, the translated survey was then verified by an outside native Spanish speaker for clarity and authenticity to the original survey document. Throughout the advocacy period, a Spanish speaking instructional assistant was present to give the students directions as 
well as read the questions aloud, since school staff affirmed that not every Spanish-speaking student was highly literate in Spanish.

School staff and the research team administered the surveys for students from all other language backgrounds on a second day. Students who wished to participate were invited to gather in rooms according to their preferred language. Students who moved to the rooms but later decided they did not wish to participate were allowed to stay in the same room if they wished to avoid social awkwardness or peer pressure to participate. To ensure that the participants were able to accurately understand the survey questions, an interpreter in each room read the questions aloud to the students in their respective languages. These interpreters had been given the English language survey in advance so they would be prepared to interpret the questions into their respective languages. They had also taught students about marking a five-point Likert scale response sheet. Students marked their responses on their own response sheet while multilingual assistants circulated in each classroom to answer questions. A similar multilingual data collection method had been used previously by the school for other purposes, so students had prior experience listening to their interpreters read questions and then indicating a response in writing.

While this data collection method has obvious limitations and raises validity questions, we were constrained not only by lack of budget for multiple translations but also by wide variations in student literacy. School administrators report that a number of students are not literate or have low literacy skills in their first language. This is one reason the school uses verbal interpretation far more often than written translation. In addition, some of the students' first languages are primarily oral languages rather than written languages. For examples, most Somali students at the school speak MaiMai (or Maay Maay) but have never read it. Without survey items to control for limited literacy, language in which the survey was administered, and first language, we were unable to interrogate potential problems created by these factors.

\section{Creation of an Analytical Construct}

Student responses to demographic questions about their nationality, ethnicity, and socioeconomic background were inconsistent. A student, for example, may not respond to country of birth but was able to answer questions about their parents' ethnicity or language. The response patterns likely reflect varied knowledge of factors related to social and economic background.

In order to determine whether students who came to the United States as refugees from distressed areas report different aspects or levels of acculturative stress compared to students who came to the U.S. through other immigration channels, we needed to find a way to identify which students were likely to have experienced traumatic stress related to their immigration experience. Since we did not want to ask questions related to immigration status directly, we looked for other data points to predict whether some students might be more likely to need counseling services. The research team made a list of students' place of birth, students' self-described ethnicity, parents' place of birth, parents' ethnicity, students' first language(s), and parents' first language(s). University researchers consulted with both school district personnel and two refugee resettlement agencies for feedback on the combination of factors used to determine a students' likelihood of experiencing traumatic stress. Based on this background information, we created a variable for "Refugees with likely Experiences of Distress" (RED) for those whose place of birth, language, and/or ethnicity suggest that push factors for migration to the U.S. likely include traumatic stress in the form of violence or some form of persecution (see Table 3 ). This was designed to be a more accurate gauge than any one of the demographic factors considered alone. For example, a student who listed her place of birth as Thailand, her parents' place of birth as Thailand, and her primary language as Thai would not be flagged with potential "RED" status. However, a student who listed her place of birth as Thailand, her parents' place of birth as Myanmar or Burma, and her primary language as Karen would be flagged with "RED" status as that confluence of factors indicates that she was likely born in a refugee camp as a refugee from Burma. 
The RED construct allowed the research team to triangulate the information we received from students to better understand the circumstances of their arrival in the U.S. By using language, ethnicity, and geographic variables related to themselves and as many as two parents, we were able to determine whether they were likely to have come to the U.S. from a place experiencing war or civil unrest. The RED construct differentiates newcomers who are more likely to have experienced traumatic distress from those who have either immigrated under less stressful conditions or who sought refugee status under less violent or volatile circumstances (such as Cubans, for example). Using this construct, each item in the survey was analyzed based on grouped output for "potential RED” participants, "non-RED” participants, and "participants for whom RED status could not be determined." About $49 \%$ of participants were identified as having potential RED status, and 51\% were identified as likely non-RED. The use of a combination of variables allowed us to maximize the ability to identify "likely RED” students despite some missing data in the demographic questionnaire preceding the survey. For example, a survey which had no response for "ethnicity" but which listed language and place of birth may still include enough data for likely RED status to be determined.

We created a construct that takes into account current migratory patterns and ethnic aspects of conflict in various parts of the world. The construct can be changed to reflect changes in the geopolitical landscape. The ever-changing nature of working with immigrant and refugee students is one reason we chose to create an analytical construct that can be updated by different counselors or schools in different areas. Cronbach's alphas indicate levels of reliability for the psychometric survey items and chi-square analyses identify whether differences between "Non-RED” and "RED” perceptions, feelings, and experiences are statistically significant.

Schools or social service agencies using a similar construct would need to update the factors determining "RED status" frequently based on immigration trends and current events. At the time of this data collection, for instance, the Spanish-speaking students in this school were all either from Cuba or Mexico. Since that time, students from Central America have enrolled who would likely not have legal refugee status but would have a high likelihood of experiencing traumatic stress. Were we to do the study again now, we would change the name of the construct so that it did not suggest refugees as the only group of students likely to have experienced distress.

\section{Results}

Two hundred and sixty-one students completed some or all of the School Counseling Needs Assessment and IAQ. Respondents ranged from age 10 to age 21 with a mean age of 14.74 and reported an average age of arrival in the U.S. of 13.33. A total of 123 girls and 114 boys responded to the sex item on the survey. The school has a school-wide Title I designation indicating a high poverty rate earning the school the right to flexibly use federal funds to provide systemic programming to meet the needs of the impoverished student population.

Students ranged from sixth to $12^{\text {th }}$ grade with one reporting " $15^{\text {th" }}$ which likely reflected the years they have spent in school. The bulk of respondents, however, were in grades six through ten so our analyses of gradebased differences in response omit the one $12^{\text {th }}$ grader and the one who indicated " $15^{\text {th" }}$ grade. There were no $11^{\text {th }}$ grade participants. Respondents reported 39 different countries of birth, with the largest numbers born in Cuba $(n=50)$ and Nepal $(n=42)$ (see Figure 1$)$. When asked about country of citizenship, ten students reported that they are not citizens of any country and another 61 did not know how to respond. An additional 34 simply did not respond to the questions, 14 reported U.S. citizenship, and an additional respondent indicated the U.S. as his or her second country of citizenship.

Null Hypothesis 1: a variable constructed from student responses to questions about their own country of origin, the parents' country of origin, and they and their family members' first languages will not provide a valid 
construct for identifying students who have experienced distress. Findings suggested the "Refugees with likely Experiences of Distress" (RED) variable is a valid construct. We rejected the null hypothesis.

The subsections of the instrument addressing language, cultural traditions, friends, social activities, family relationships, and self-esteem did not show statistically significant differences between likely RED and non-RED students. Despite these findings, further analysis of subgroups provides support for use of a RED variable. When we compare Cuban and Nepali Bhutanese students, the two most populous linguistic and cultural groups in the school, the two groups' responses are significantly different for several categories of the Immigrant Adolescent Questionnaire. Both Cuban and Nepali Bhutanese students are refugees. Yet Cuban immigrants were not as likely to have experienced an extreme level of distress before their arrival, whereas ethnic Bhutanese immigrants from Nepal were seeking resettlement after decades of instability in refugee camps. For this reason, students born in Cuba were coded "likely non-RED" and students born in Nepal were coded "likely RED" for the purpose of this research. The differences in lived experience between these two groups serve as an example that the likelihood of traumatic stress differs even among youth entering the U.S. as refugees.

Null Hypothesis 2: student responses will indicate the same levels of acculturative and migratory stress for those who are likely to have experienced distress compared to those without such a history. Results indicated that the majority of students at the newcomer school report positive attitudes toward school, do not report difficulties concentrating or strong feelings of loneliness (Table 1). Likely RED students reported more positive attitudes toward school than likely non-RED students in terms of "liking" school, believing that their teachers care about them and their success, and caring about their own grades and performance. However, likely RED students showed potential signs of acculturative stress regarding questions about school performance: they were more likely to agree that they have difficulty concentrating during class and while doing homework (Table 1). Likely RED students were also more likely to say they wish they "could quit school for good" (see Table 1). We rejected the null hypothesis that prior experiences of distress have no impact on acculturative and migratory stress.

Null Hypothesis 3: student response will indicate the same perceptions of discrimination for those who are likely to have experienced distress and those without such a history.

The IAQ includes nine indicators of perceived discrimination. In our sample, only four of those indicators appear to load on the same factor (Cronbach's Alpha $=.71$ ). Students at the newcomer school generally report a positive and supportive school environment with little difference between students who are likely to have experienced trauma prior to their arrival and the rest of the group (see Table 2). However, the school is not necessarily a multiethnic utopia. Chi-square tests indicate an association between likely experiences of distress (RED) and perceptions of discrimination on the following items:

- "I have been teased or insulted because of my ethnic background," $\chi^{2}(4, N=207)=10.25, p<0.05$.

- "I have been threatened or attacked because of my ethnic background," $\chi^{2}(4, N=207)=12.24, p<$ 0.05 .

- "Other students have treated me unfairly or negatively because of my ethnic background," $\chi^{2}(4, N=$ $207)=10.74, p<0.05$.

Students identified as having likely RED status are more likely to perceive ethnic discrimination and their responses differ significantly $(p<.05)$ from non-RED student responses for each of the statements (see Figure 2). We reject the null hypothesis of no association between prior experiences of distress and perceptions of discrimination. The instrument does not specify a time-frame for these experiences, so students may report experiences from prior to their arrival at the newcomer school. Most students at the school enroll immediately upon arrival in the community, so most would not have much prior experience in U.S. culture (and thus few prior discriminatory interactions, one might assume) before attending the current school. Teasing and harassment based on ethnicity do not appear to be common problems, but the differences in responses between 
RED students and non-RED students is both statistically significant and reflective of a clear divergence in perceptions of discrimination.

In previous research, perceived discrimination among adolescent refugees has been linked to greater posttraumatic stress symptoms (Ellis, MacDonald, Lincoln, \& Cabral, 2008) and has been studied in the context of bullying of refugee students (Mthethwa-Sommers \& Kisiara, 2015). This literature supports our assertion that perceived discrimination among newcomers - and culturally and linguistically diverse students in generalshould remain an issue of concern among school psychologists, school counselors, and other school staff.

\section{Discussion}

When school systems plan instructional and non-instructional services for English language learners, too often they focus almost exclusively on linguistic needs. In this assessment-focused era when the results of high-stakes testing may be closely tied to resource allocation, administrators and educators tend to emphasize reaching English language proficiency above all other educational priorities. Yet as decades of research on immigrant acculturation and as more recent research on childhood traumatic experiences has shown, positive educational outcomes rely on more than high-quality classroom instruction. The findings of this study support the significance of traumatic stress on adolescent students' experiences of acculturation by showing that students who were more likely to have experienced situations of trauma responded differently-regardless of any single other variable - than students who were less likely to have experienced such trauma. The findings also support the value of being aware of immigration trends and patterns in refugee resettlement and creating or adapting an analytical construct such as the RED variable. We hope these findings will encourage other school counselors, educators, and social service providers to provide increased support for immigrant and refugee students who need treatment due to traumatic experiences-as well as to take the social and political context of students' backgrounds into consideration when planning for such services. Educational funding is limited nationwide, and schools need evidence to justify requests for more mental health services. This study is one approach to collecting such data.

\section{Limitations}

Limitations of the study include methodological weaknesses which raise questions about the validity, reliability, and generalizability of specific data points. Although school administrators requested this study, numerous logistical barriers constrained the research design and data collection, including limited available classroom time, inadequate resources to fund paper survey translation to all languages, participant literacy limitations in multiple languages, participant age, parental consent, the large number of languages spoken by students, and the need to train interpreters.

One critical error in research design was choosing an instrument too long and complex for the time allowed for data collection. The school counselor noted the length and linguistic complexity of the instrument and requested that we shorten it. While we worried about affecting the validity of the research instrument, we also shared her concerns. We ultimately chose to remove five of the original ten questions in the negative activities subscale and three of the original thirteen questions in the ethnic identity subscale. Our rationale was that any data we collected might help school administrators advocate for increased services to meet the needs of its most vulnerable students. However, we failed to do any tests to explore how the instrument's validity would be affected by those changes. Because of those methodological problems, we report only on findings from sections of the IAQ with unaltered questions. We also underestimated how long administering the instrument would take when interpretation was taken into account. Due to this issue, the response rate of subsections among students who chose to take the survey plummeted from $94.6 \%$ in the first two sections of the survey to 
$53.3 \%$ in the final section of the survey. Because of these issues, we report here only on findings with at least $60 \%$ completion rates (thus removing the subsections of psychosomatic symptoms and negative activities.)

Any construct such as RED/non-RED status is built on broad generalizations and therefore has many limitations. Nevertheless, the findings indicate that looking at a confluence of factors in a student's background may yield more insight than the information schools often consider, which is that students from both groups are simply "English language learners."

Because of the rapidly changing demographics of immigrant and refugee students in our school system, the conditions of the study would not be replicable if we undertook this project again today. We welcome others to modify and improve this preliminary effort with more robust studies to meet the needs of the current refugee and immigrant populations in their communities.

\section{Implications}

Results from the study support the claim that trauma and distress affect students' attitudes toward school and perceptions of discrimination. As such, the RED construct may serve as a useful tool for local education agencies and social service providers as they collect demographic data for the purposes of planning distribution of resources to meet the needs of their immigrant and refugee populations. While a factor such as "RED status" would certainly not replace standard professional practice for serving individual students, creating such a construct to fit the population of a school district could allow schools to estimate numbers of students who have a higher likelihood of needing services beyond the figures that a school district would typically provide. This estimating capacity is powerful for school administrators who must project and substantiate any need for additional personnel or training in their budgetary requests. The data collected from students' likely RED status would preserve the privacy of students' immigration status while still providing the administration with data that could bolster its case in a petition to the district for an additional school counselor or mental health professional on staff.

Lessons learned include the need for a construct such as "RED status" to change over time to reflect shifting geopolitical realities. Since immigration and refugee resettlement patterns differ across the country, schools in different communities work with students from nations and cultural groups that may not be reflected in our sample. We hope the example of constructing the RED variable sparks further thinking about how to better understand the needs of newcomer students based on the paths that brought them to the U.S. and the trauma they may have experienced before, during, and since their arrival. Since the cultural and historical experiences of each cultural immigrant group are different, school counselors and psychologists who work with refugee and immigrant populations would need to adapt this construct just as they adapt other service strategies for newcomer groups (Walick \& Sullivan, 2015). As global migration patterns continue to shift, school personnel will continue to need information and resources to empower them with the knowledge and skills to plan and implement effective programs for immigrant and refugee children.

\section{Conclusion}

The school counselor at this newcomer program was able to use the statistically significant findings from this study to advocate successfully for a full-time mental health counselor. We offer the lessons learned from this study as both an example of the value of engaged scholarship and an encouragement to other counseling professionals who work with immigrant and refugee adolescents to think creatively about ways to capture useful data to advocate for increased services students may need. 


\section{Author Contact Information}

Please address correspondence about this article to Lisa Hoffman, School of Education, Indiana University Southeast, 4201 Grant Line Road, New Albany, IN 47150-6405. Email: 1hh@ius.edu. 


\section{References}

Aydıngün, A., Harding, Ç, Hoover, M., Kuznetsov, I., Swerdlow, S. (2006). Meskhetian Turks:

An introduction to their history, culture, and resettlement experiences. Washington, DC: Cultural Orientation Resource Center, Center for Applied Linguistics. Retrieved from http://www.culturalorientation.net/ learning/backgrounders/list-of-refugee-backgrounders

Bentley, J. A., Thoburn, J. W., Stewart, D. G., \& Boynton, L. D. (2012). Post-migration stress as a moderator between traumatic exposure and self-reported mental health symptoms in a sample of Somali refugees. Journal of Loss and Trauma, 17, 452-469.

Berry, J.W., Phinney, J.S., Sam, D.L., \& Vedder, P. (2006). Immigrant youth in cultural transition: Acculturation, identity, and adaptation across national contexts. Mahwah, NJ: Lawrence Erlbaum Associates.

Birman, D., \& Chan, W. Y. (2008). Screening and assessing immigrant and refugee youth in school based mental health programs. Center for Health and Health Care in Schools. Retrieved from www.healthinschools.org.

Birman, D., Ho, J., Pulley, E., Batia, K., Everson, M.L., Ellis, H., Stichick Betancourt, T., Gonzalez, A. (2005). Mental health interventions for refugee children in resettlement. White Paper II, Refugee Trauma Task Force, National Child Traumatic Stress Network, Chicago, IL. Retrieved from http://www.nctsnet.org/ nctsn assets/pdfs/materials for applicants/MH interventions for Refugee Children.pdf

Center for Victims of Torture. (2005). Healing the hurt: A guide for developing services for torture survivors. Minneapolis, MN: The Center for Victims of Torture. Retrieved from http://www.cvt.org/resources/ publications.

Cisneros, J., \& Lopez, A. (2016). DREAMzone: Educating counselors and human service professionals working with undocumented students. Journal for Social Action in Counseling and Psychology, 8 (2), 32-48.

Cole, S. F., O’Brien, J. G., Gadd, M. G., Ristuccia, J., Wallace, D. L., \& Gregory, M. (2005). Helping traumatized children learn: A report and policy initiative. Boston: Massachusetts Advocates for Children: Trauma and Learning Policy Initiative.

Craig, S. E. (2016). Trauma-sensitive schools: Learning communities transforming children's lives, K-5. New York: Teachers College Press.

Dodds, A. E. (2010). Children of Somali refugees in Australian schools: Self-descriptions of school-related skills and needs. International Journal of Behavioral Development, 34, 521-528.

Doran-Myers, D., \& Davies, S.C. (2009). School-based services for traumatized refugee children. Counselor Education and Human Services Faculty Publications, Paper 14. http://ecommons.udayton.edu/edc fac $\mathrm{pub} / 14$

Ellis, B. H., MacDonald, H. Z., Lincoln, A. K., \& Cabral, H. J. (2008). Mental health of Somali adolescent refugees: The role of trauma, stress, and perceived discrimination. Journal of Consulting and Clinical Psychology, 76, 184-193.

Fazel, M., Garcia, J., \& Stein, A. (2016). The right location? Experiences of refugee adolescents seen by schoolbased mental health services. Clinical Child Psychology and Psychiatry, 21(3), 368-380.

Felitti, V. J., Anda, R. F., Nordenberg, D., Williamson, D. F., Spitz, A. M., Edwards, V., Koss, M. P., \& Marks, J. S. (1998). Relationship of childhood abuse and household dysfunction to many of the leading causes of death in adults: The adverse childhood experiences (ACE) study. American Journal of Preventive Medicine, 14, 245-258. 
Ghumman, U., McCord, C. E., \& Chang, J. E. (2016). Posttraumatic stress disorder in Syrian refugees: A review. Canadian Psychology, 57, 246-253. http://doi.org/10.1037/cap0000069

Horsford, S. D. \& Sampson, C. (2013). High ELL growth states: Expanding funding equity and opportunity for English language learners. Voices in Urban Education, 37. Retrieved from http://vue. annenberginstitute.org/issues/37/high-ell-growth-states

Hurt, H., Malmud, E., Brodsky, N.L., \& Gianetta, J. (2001). Exposure to violence: Psychological and academic correlates in child witnesses. Archives of Pediatrics and Adolescent Medicine, 155, 1351-1356.

Izyumov, A., Nahata, B., \& Coomes, P. (2002). Immigration to the Louisville Metropolitan Area: Recent trends, policy recommendations. Brandeis Law Journal, 40, 909-932.

Kartal, D., \& Kiropoulos, L. (2016). Effects of acculturative stress on PTSD, depressive, and anxiety symptoms among refugees resettled in Australia and Austria. European Journal of Psychotraumatology, 7, 10.3402/ ejpt.v7.28711. http://doi.org/10.3402/ejpt.v7.28711

Kia-Keating, M., \& Ellis, B. H. (2007). Belonging and connection to school in resettlement: Young Refugees, School Belonging, and Psychosocial Adjustment. Clinical Child Psychology \& Psychiatry, 12, 29-43.

Knipscheer, J., Drogendijk, A., Gülsen, C., \& Kleber, R. (2009). Differences and similarities in posttraumatic stress between economic migrants and forced migrants: Acculturation and mental health within a Turkish and a Kurdish sample. International Journal of Clinical and Health Psychology, 9, 373-391.

McCloskey, L. A., Southwick, K. (1996). Psychosocial problems in refugee children exposed to war. Pediatrics, 97, 394-97.

Mossaad, D. (2016, November) Refugees and asylees: 2015. Annual Flow Report. Washington, DC: United States Department of Homeland Security Office of Immigration Statistics. Retrieved from https://www. dhs.gov/sites/default/files/publications/Refugees Asylees 2015.pdf

Mthethwa-Sommers, S., \& Kisiara, O. (2015). Listening to students from refugee backgrounds: Lessons for education professionals. Penn GSE Perspectives on Urban Education, 12, np.

Nugent, N., \& Roberts, S. (2013). Child and adolescent refugees: From surviving to thriving. Brown University Child \& Adolescent Behavior Letter, 29, 1-7.

Oehlberg, B. (2008). Why schools need to be trauma informed. Trauma and Loss: Research and Interventions, 8(2). Retrieved from http://www.traumainformedcareproject.org/resources/ WhySchoolsNeedToBeTraumaInformed(2).pdf

Porter, M., \& Haslam, N. (2005). Predisplacement and postdisplacement factors associated with mental health of refugees and internally displaced persons: A meta-analysis. JAMA: Journal of the American Medical Association, 294, 602-612.

Reyes, J. A. \& Elias, M. J. (2011). Fostering social-emotional resilience among Latino youth. Psychology in the Schools, 48, 723-737. http://doi.org/10.1002/pits.20580

Robbins, L., \& Jordan, M. (2018, May 16). Apartments are stocked, toys donated. Only the refugees are missing. The New York Times. Retrieved from https://www.nytimes.com

Rojas-Flores, L., Clements, M. L., Hwang Koo, J., \& London, J. (2017). Trauma and psychological distress in Latino citizen children following parental detention and deportation. Psychological Trauma: Theory, Research, Practice, and Policy, 9(3), 352-361. https://doi-org.proxyse.uits.iu.edu/10.1037/tra0000177

Rossen, E., \& Cowan, K. (2013). The role of schools in supporting traumatized students. Principal's Research Review, 8, 1-8. 
Roth, B. J., Crea, T. M., Jani, J., Underwood, D., Hasson III, R. G., Evans, K., \& Zuch, M. (In press). Detached and afraid: U.S. immigration policy and the practice of forcibly separating parents and young children at the border. Child Welfare.

Segal, U.A., \& Mayadas, N.S. (2005). Assessment of issues facing immigrant and refugee families. Child Welfare, 34, 563-583.

Shannon, P. J., Vinson, G. A., Wieling, E., Cook, T., \& Letts, J. (2015). Torture, war trauma, and mental health symptoms of newly arrived Karen refugees. Journal of Loss \& Trauma, 20, 577-590.

Short, D. J. (2002). Newcomer programs: An educational alternative for secondary immigrant students. Education and Urban Society, 34, 173-198.

Short, D. J., \& Boyson, B. A. (2012). Helping newcomer students succeed in secondary schools and beyond: A report to Carnegie Corporation of New York. Washington, DC: Center for Applied Linguistics. Retrieved from http://www.cal.org/resource-center/publications-products/helping-newcomer-students

Sirin, S. R., \& Rogers-Sirin, L. (2015). The educational and mental health needs of Syrian refugee children. Washington, DC: Migration Policy Institute.

Torres, S. A., Santiago, C. D., Walts, K. K., \& Richards, M. H. (2018). Immigration policy, practices, and procedures: The impact on the mental health of Mexican and Central American youth and families. American Psychologist, 73, 843-854. http://dx.doi.org/10.1037/amp0000184

Transactional Records Access Clearinghouse. (2016). Continued rise in asylum denial rates: Impact of representation and nationality. Syracuse University TRAC. Retrieved from http://trac.syr.edu/ immigration/reports/448/

Trickett, E. J., \& Birman, D. (2004). Acculturation, school context, and school outcomes: Adaptation of refugee adolescents from the former Soviet Union. Psychology in the Schools, 42, 27-38. http://doi.org/10.1002/ pits. 20024

Tyrer, R. A., \& Fazel, M. (2014). School and community-based interventions for refugee and asylum seeking children: A systematic review. PLoS ONE, 9(2), 1-10. http://doi.org/10.1371/journal.pone.0089359

UNHCR. (2018a). Refugee Facts: What Is a Refugee? Retrieved from https://www.unrefugees.org/refugee-facts/ what-is-a-refugee/

----. (2018b). Population Statistics. Retrieved from http://popstats.unhcr.org/en/asylum seekers monthly

U.S. Citizenship and Immigration Services. (2015). Refugees \& Asylum. Retrieved from https://www.uscis.gov/ humanitarian/refugees-asylum

United States Department of Justice, Civil Rights Division, \& United States Department of

Education, Office for Civil Rights. (2014). Fact sheet: Information on the rights of all children to enroll in school. Retrieved from http://www.justice.gov/crt/guidance

Walick, C. M., \& Sullivan, A. L. (2015). Educating Somali immigrant and refugee students: A review of cultural-historical issues and related psychoeducational supports. Journal of Applied School Psychology, 31, 347-368.

Yakushko, O., \& Morgan Consoli, M. L. (2014). Politics and research of immigration: Implications for counseling and psychological scholarship and action. Journal for Social Action in Counseling and Psychology, 6 (1), 98-121.

Zhou, Z., Peverly, S. T., Xin, T., Huang, A. S., \& Wang, W. (2003). School adjustment of first-generation Chinese-American adolescents. Psychology in the Schools, 40, 71-84. http://doi.org/10.1002/pits.10070 
Figure 1. Participants' Country of Birth.

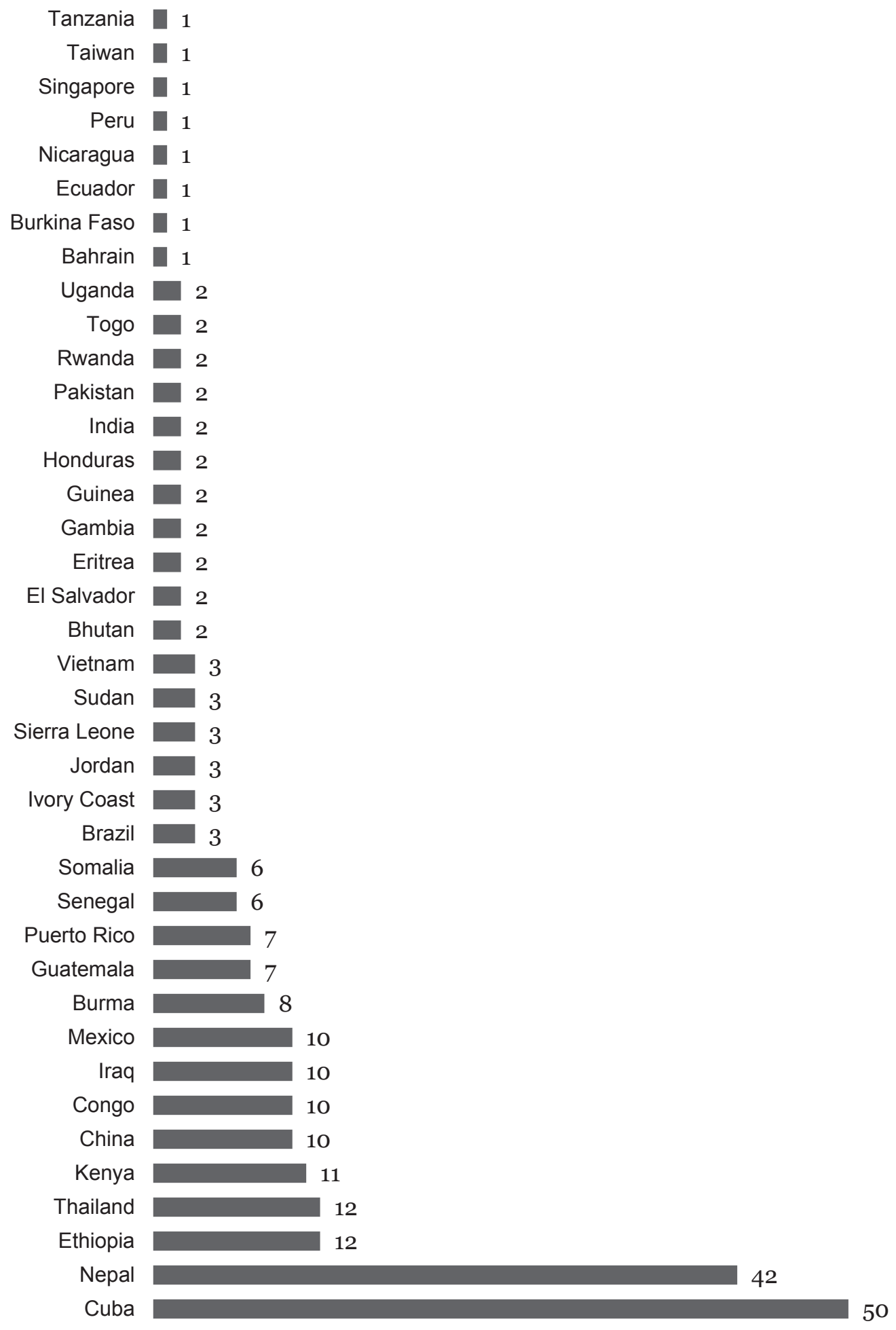


Figure 2. Responses to item: "I have been teased or insulted because of my ethnic background."

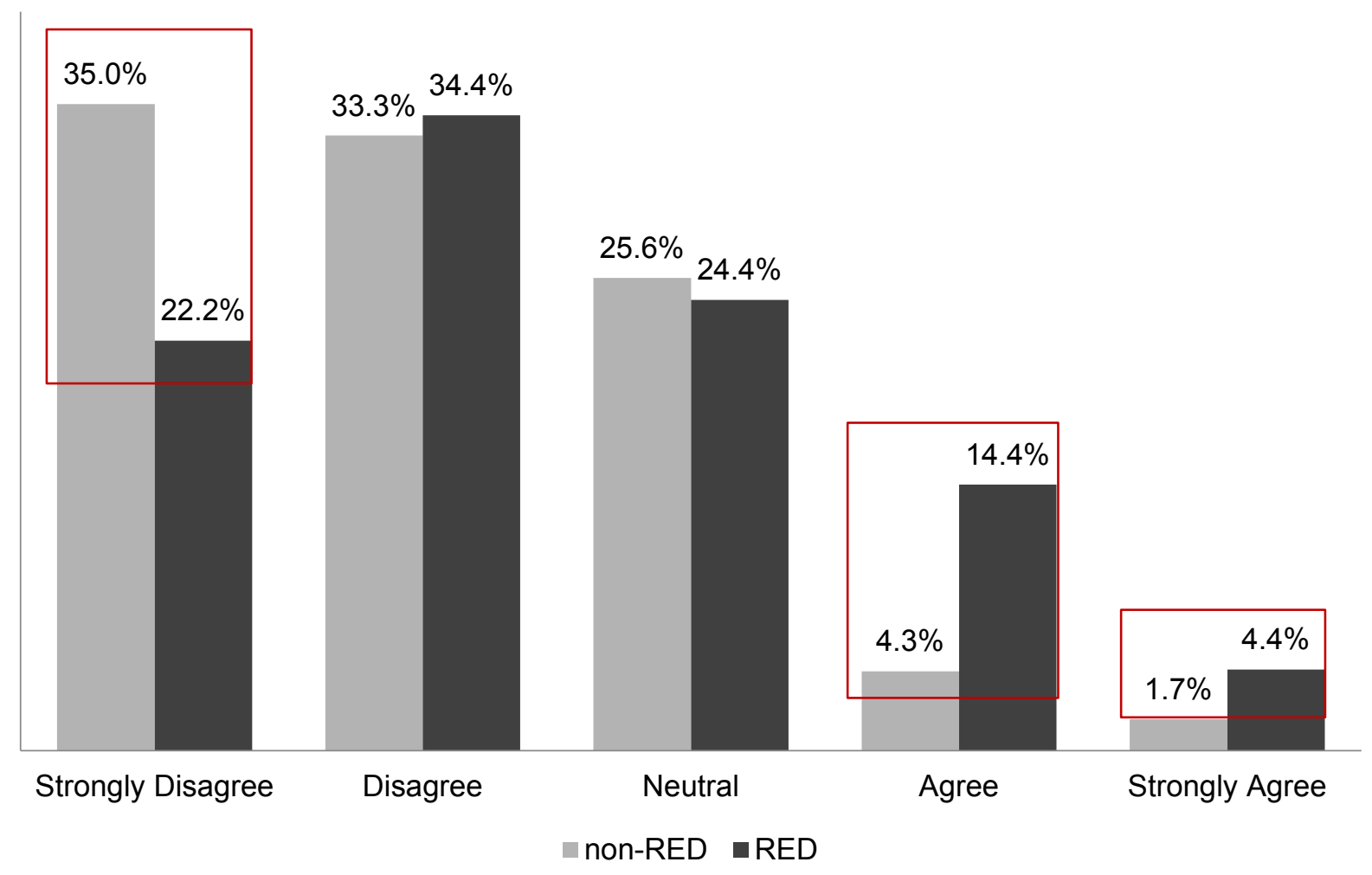




\section{Table 1}

School Adjustment-Acculturative Stress and Feelings about School, All Students, non-RED ${ }^{\gamma}$, and RED

School Adjustment: Component 1-Acculturative Stress and School Adjustment ${ }^{\#}$

\begin{tabular}{|c|c|c|c|c|c|}
\hline Survey Item & Survey Response & $\begin{array}{c}\text { All } \\
\text { Students }\end{array}$ & $\begin{array}{l}\text { Non- } \\
\text { RED }\end{array}$ & RED & Chi-Square \\
\hline \multirow{5}{*}{$\begin{array}{l}\text { I have problems } \\
\text { concentrating during class. } \\
\text { (Loading }=.83 \text { ) }\end{array}$} & Strongly Disagree & $26.8 \%$ & $28.1 \%$ & $24.4 \%$ & \multirow{5}{*}{$\begin{array}{c}10.09^{*} \\
(4, n=244)\end{array}$} \\
\hline & Disagree & $24.5 \%$ & $24.8 \%$ & $25.2 \%$ & \\
\hline & Neutral & $24.1 \%$ & $24.8 \%$ & $23.6 \%$ & \\
\hline & Agree & $18.3 \%$ & $20.7 \%$ & $15.4 \%$ & \\
\hline & Strongly Agree & $6.1 \%$ & $1.7 \%$ & $11.4 \%$ & \\
\hline \multirow{5}{*}{$\begin{array}{l}\text { I have problems } \\
\text { concentrating when doing } \\
\text { homework. } \\
\text { (Loading }=.76 \text { ) }\end{array}$} & Strongly Disagree & $28.8 \%$ & $35.5 \%$ & $22.0 \%$ & \multirow{5}{*}{$\begin{array}{c}15.97^{* *} \\
(4, n=244)\end{array}$} \\
\hline & Disagree & $31.1 \%$ & $28.9 \%$ & $33.3 \%$ & \\
\hline & Neutral & $15.6 \%$ & $14.0 \%$ & $16.3 \%$ & \\
\hline & Agree & $16.3 \%$ & $19.0 \%$ & $13.8 \%$ & \\
\hline & Strongly Agree & $8.2 \%$ & $2.5 \%$ & $14.6 \%$ & \\
\hline \multirow{5}{*}{$\begin{array}{l}\text { I wish I could quit school for } \\
\text { good. } \\
\text { (Loading }=.67 \text { ) }\end{array}$} & Strongly Disagree & $53.3 \%$ & $62.8 \%$ & $44.7 \%$ & \multirow{5}{*}{$\begin{array}{c}11.49^{*} \\
(4, n=243)\end{array}$} \\
\hline & Disagree & $23.7 \%$ & $22.3 \%$ & $26.0 \%$ & \\
\hline & Neutral & $12.1 \%$ & $9.1 \%$ & $14.6 \%$ & \\
\hline & Agree & $5.8 \%$ & $1.7 \%$ & $8.1 \%$ & \\
\hline & Strongly Agree & $5.1 \%$ & $4.1 \%$ & $6.5 \%$ & \\
\hline
\end{tabular}


School Adjustment: Component 2-Feelings about School ${ }^{\# \#}$

\begin{tabular}{|c|c|c|c|c|c|}
\hline Survey Item & Survey Response & $\begin{array}{c}\text { All } \\
\text { Students }\end{array}$ & $\begin{array}{l}\text { Non- } \\
\text { RED }\end{array}$ & RED & Chi-Square \\
\hline \multirow{5}{*}{$\begin{array}{l}\text { I believe my teachers care } \\
\text { about me and my success. } \\
\text { (Loading }=.85 \text { ) }\end{array}$} & Strongly Disagree & $8.2 \%$ & $12.5 \%$ & $4.9 \%$ & \multirow{5}{*}{$\begin{array}{c}13.10^{*} \\
(4, n=243)\end{array}$} \\
\hline & Disagree & $4.7 \%$ & $5.0 \%$ & $4.1 \%$ & \\
\hline & Neutral & $16.0 \%$ & $22.5 \%$ & $10.6 \%$ & \\
\hline & Agree & $34.8 \%$ & $28.3 \%$ & $39.0 \%$ & \\
\hline & Strongly Agree & $36.3 \%$ & $31.7 \%$ & $41.5 \%$ & \\
\hline \multirow{5}{*}{$\begin{array}{l}\text { I care about my grades and } \\
\text { how I do in my school work. } \\
\text { (Loading }=.83 \text { ) }\end{array}$} & Strongly Disagree & $2.3 \%$ & $3.3 \%$ & $1.6 \%$ & \multirow{5}{*}{$\begin{array}{c}7.89^{\dagger} \\
(4, n=243)\end{array}$} \\
\hline & Disagree & $4.3 \%$ & $5.8 \%$ & $2.4 \%$ & \\
\hline & Neutral & $10.5 \%$ & $12.5 \%$ & $9.8 \%$ & \\
\hline & Agree & $34.4 \%$ & $38.3 \%$ & $29.3 \%$ & \\
\hline & Strongly Agree & $48.4 \%$ & $40.0 \%$ & $56.9 \%$ & \\
\hline \multirow{5}{*}{$\begin{array}{l}\text { At present, I like school. } \\
\text { (Loading }=.68)\end{array}$} & Strongly Disagree & $5.8 \%$ & $9.1 \%$ & $3.3 \%$ & \multirow{5}{*}{$\begin{array}{c}35.15^{* *} \\
(4, n=244)\end{array}$} \\
\hline & Disagree & $4.7 \%$ & $9.9 \%$ & $0.0 \%$ & \\
\hline & Neutral & $7.8 \%$ & $14.0 \%$ & $1.6 \%$ & \\
\hline & Agree & $40.1 \%$ & $36.4 \%$ & $43.1 \%$ & \\
\hline & Strongly Agree & $41.6 \%$ & $30.6 \%$ & $52.0 \%$ & \\
\hline
\end{tabular}

${ }^{\gamma}$ RED stands for Refugees Experiencing Distress. Non-RED refers to students whose responses indicate they are not likely to be experiencing distress.

${ }^{\#}$ Component 1: The acculturative stress and school adjustment indicators hang together and the common construct explains $56.9 \%$ of the variance, but the reliability is weaker than preferred, Cronbach's Alpha $=.58$. Loadings are higher than in Berry's et al. multinational sample, and the construct appears to explain more of the variance than in the multinational immigrant sample.

${ }^{\#}$ Component 2: The attitude toward school indicators hang together well, and the attitude construct is estimated to explain $62.23 \%$ of the variance and is relatively reliable with a Cronbach's Alpha of .69

$\dagger$ Chi-Square borderline significance $.05<p<.10$. Not statistically significant, but borderline.

${ }^{*}$ Chi-Square significant at $.01<p<.05$ level.

${ }^{*}$ Chi-Square significant at $p<.01$ level. 


\section{Table 2}

Perceived Discrimination, All Students, non-RED ${ }^{\gamma}$, and RED

\begin{tabular}{|c|c|c|c|c|c|}
\hline \multirow{6}{*}{$\begin{array}{l}\text { I have been teased or } \\
\text { insulted because of my } \\
\text { ethnic background. } \\
\text { (Loading }=.80 \text { ) }\end{array}$} & Survey Response & $\begin{array}{c}\text { All } \\
\text { Students }\end{array}$ & $\begin{array}{l}\text { Non- } \\
\text { RED }\end{array}$ & RED & Chi-Square \\
\hline & Strongly Disagree & $29.8 \%$ & $35.0 \%$ & $22.2 \%$ & \multirow{5}{*}{$\begin{array}{c}10.25^{*} \\
(4, n=207)\end{array}$} \\
\hline & Disagree & $33.0 \%$ & $33.3 \%$ & $34.4 \%$ & \\
\hline & Neutral & $26.1 \%$ & $25.6 \%$ & $24.4 \%$ & \\
\hline & Agree & $8.3 \%$ & $4.3 \%$ & $14.4 \%$ & \\
\hline & Strongly Agree & $2.8 \%$ & $1.7 \%$ & $4.4 \%$ & \\
\hline \multirow{5}{*}{$\begin{array}{l}\text { I have been threatened or } \\
\text { attacked because of my } \\
\text { ethnic background. } \\
\text { (Loading }=.81 \text { ) }\end{array}$} & Strongly Disagree & $33.0 \%$ & $40.2 \%$ & $23.3 \%$ & \multirow{5}{*}{$\begin{array}{c}12.24^{*} \\
(4, n=207)\end{array}$} \\
\hline & Disagree & $32.6 \%$ & $29.9 \%$ & $36.7 \%$ & \\
\hline & Neutral & $25.7 \%$ & $24.8 \%$ & $26.7 \%$ & \\
\hline & Agree & $6.4 \%$ & $5.1 \%$ & $7.8 \%$ & \\
\hline & Strongly Agree & $2.3 \%$ & $0.0 \%$ & $5.6 \%$ & \\
\hline \multirow{5}{*}{$\begin{array}{l}\text { Other students have treated } \\
\text { me unfairly or negatively } \\
\text { because of my ethnic } \\
\text { background. } \\
\text { (Loading }=.81 \text { ) }\end{array}$} & Strongly Disagree & $28.0 \%$ & $31.6 \%$ & $22.2 \%$ & \multirow{5}{*}{$\begin{array}{c}10.74^{*} \\
(4, n=207)\end{array}$} \\
\hline & Disagree & $29.4 \%$ & $29.1 \%$ & $32.2 \%$ & \\
\hline & Neutral & $27.5 \%$ & $30.8 \%$ & $22.2 \%$ & \\
\hline & Agree & $8.7 \%$ & $5.1 \%$ & $12.2 \%$ & \\
\hline & Strongly Agree & $6.4 \%$ & $3.4 \%$ & $11.1 \%$ & \\
\hline \multirow{5}{*}{$\begin{array}{l}\text { Other kids/ teens outside } \\
\text { school have treated me } \\
\text { unfairly or negatively } \\
\text { because of my ethnic } \\
\text { background. } \\
\text { (Loading .68) }\end{array}$} & Strongly Disagree & $27.6 \%$ & $34.2 \%$ & $30.0 \%$ & \multirow{5}{*}{$\begin{array}{c}3.31 \\
(4, n=207)\end{array}$} \\
\hline & Disagree & $26.8 \%$ & $31.6 \%$ & $34.4 \%$ & \\
\hline & Neutral & $20.7 \%$ & $27.4 \%$ & $22.2 \%$ & \\
\hline & Agree & $6.1 \%$ & $5.1 \%$ & $8.9 \%$ & \\
\hline & Strongly Agree & $2.3 \%$ & $1.7 \%$ & $4.4 \%$ & \\
\hline
\end{tabular}

${ }^{r}$ RED stands for Refugees Experiencing Distress. Non-RED refers to students whose responses indicate they are not likely to be experiencing distress.

* Pearson Chi-Square test for significant differences in ordinal responses by respondent group is significant with $01<p<.05$ level, Cronbach's Alpha $=.709$. When all 9 IAQ discrimination items are included, Cronbach's Alpha is .809 , but that seems to reflect some statistical noise as several items have low loadings and even some negative loadings. This construct has slightly lower reliability, but strong loadings that are clearly loading on just one component. The component explains an estimated $55.1 \%$ of the variance. Loadings are higher than the averages in Berry et al.'s multinational work. 


\section{Table 3}

Variable Construction for Refugees with Likely Experiences of Distress (RED)

\section{Place of birth}

When students indicated that they or either of their parents were born in one of the following countries, they were coded as RED (with a few qualified cases noted below).

\section{Bhutan}

Burma (may be listed as Myanmar)

Burundi

Congo

Eritrea

Haiti

Iraq

Kenya - IF ethnicity OR language OR either parent's ethnicity or language is listed as Burundian or Sudanese or Dinka; or if either parents' place of birth is listed as Burundi or Sudan.*

Liberia

Malaysia - IF ethnicity OR language OR either parent's ethnicity or language is listed as Karen, Karenni, Chin, or Burmese; or if either parents' place of birth is listed as Burma or Myanmar.*

Nepal

Somalia

Sudan

Thailand - IF ethnicity OR language OR either parent's ethnicity or language is listed as Karen, Karenni, Chin, or Burmese; or if either parents' place of birth is listed as Burma or Myanmar.*

\section{Language}

If students indicated one of the following languages as a first language (with additional qualifications noted), they were coded as RED.

Arabic - IF place of birth is listed as Iraq or ethnicity is listed as Iraqi.

Bhutanese

Burmese

Chin

French - IF ethnicity OR either parent's ethnicity is listed as Haitian or Congolese; OR if either parents' place of birth is listed as Haiti or Congo.

Karen

Karenni (may be listed as Red Karen or Kayah)

Kikongo 


\section{Lingala}

Nepalese (may be listed as Nepali)

Somali

Swahili - IF ethnicity OR either parent's ethnicity is listed as Congolese; OR if either parents' place of birth is listed as the Congo.

Tigrinya

\section{Ethnicity}

If students indicated their own or either of their parent's ethnicity as one of the following, they were coded as RED. Some participants may have listed nationality, so many options are possible.

Arab - IF place of birth is listed as Iraq.

Bhutanese

Burmese

Burundian

Chin

Congolese

Dinka

Eritrean

Haitian

Iraqi

Karen

Karenni

Kurd

Liberian

Meskhetian Turk

Nepali (may be listed as Nepalese)

Somali

Sudanese

Tigrinya

* These items are designed to capture data from students born in refugee camps. 